Philosophy and

Phenomenological Research

Philosophy and Phenomenological Research

Vol. XCI No. 1, July 2015

doi: $10.1111 /$ phpr. 12110

(C) 2014 Philosophy and Phenomenological Research, LLC

\title{
Shame, Violence, and Morality
}

\author{
KRISTA K. THOMASON \\ Swarthmore College
}

\begin{abstract}
Shame is most frequently defined as the emotion we feel when we fail to live up to standards, norms, or ideals. I argue that this definition is flawed because it cannot explain some of the most paradigmatic features of shame. Agents often respond to shame with violence, but if shame is the painful feeling of failing to live up to an ideal, this response is unintelligible. I offer a new account of shame that can explain the link between shame and violence. On my view, shame arises out of a tension between our identity and our self-conception: those things about which we feel shame are part of our identities, but they are not part of our self-conception. I conclude by arguing that this account of shame is a valuable moral emotion.
\end{abstract}

Heidi Maibom summarizes the account of shame that has dominated the literature of moral psychology for the past 40 years: "Shame is a painful emotion concerned with the failure to live up to certain standards, norms, and ideals" (2010: 566). The notion that shame is fundamentally about failing to live up to standards has persisted in the literature since Rawls. The accounts that accept this definition of shame are of course not univocal. There is some disagreement over how precisely to understand the nature of failure: is it a blow to self-esteem, self-respect, or self-relevant values? $^{1}$ Other disagreements are about the nature of the standards. ${ }^{2}$ Must the agent accept the standards that she fails to live up to or are the standards social or public standards? Philosophers likewise disagree about whether or not shame conceived in this way can play a positive role in moral life. ${ }^{3}$ But the core aspects of the account are the same: "With few exceptions...everybody agrees that failing to live up to standards, norms and ideals is absolutely central to shame" (Maibom, 2010: 569).

Deigh (1983), Taylor (1985), Rawls (2003), Deonna et. al. (2012).

2 Maibom (2010), Calhoun (2004), Roberts (2003), Williams (1993), Kekes (1988).

3 Nussbaum (2004), Manion (2002), Kekes (1988). 
In spite of its success, I will argue that the traditional definition of shame is flawed. Philosophical accounts of moral emotions face two challenges. The traditional view of shame meets the first challenge: explaining how an emotion has moral value and what role it plays in moral life. The other challenge is good conceptual analysis of the emotion. That is, our philosophical accounts of emotions should match the way we experience it. I will argue that the traditional definition fails to meet this second challenge. I will illustrate how it fails to meet this challenge by examining cases in which agents respond to shame with violence or aggression. ${ }^{4}$ If shame is the painful feeling of not living up to one's values, it does not make sense that agents would respond to that feeling by doing something morally bad. What is more, doing something violent alleviates feelings of shame. If the traditional view is right, this experience is impossible: doing something morally wrong should make agents feel more shame rather than less. I will argue that the attempts from the traditional view to explain away cases like these are unsuccessful. This account cannot make sense of violent or aggressive responses to shame.

In response, I will offer an alternative account of shame that makes sense of violent responses but can still explain how shame is a moral emotion. Shame, on my view, arises when we feel some aspect of our identities defines us. If I feel shame about my face, for instance, it is because I feel as though my face overshadows the rest of me. The key element of shame is that it arises out of a tension between our identity and our selfconception: those things about which we feel shame are part of our identities, but they are not part of our self-conception. I argue further that this experience has moral value by examining what is wrong with shamelessness. The shameless person takes her own self-conception to be the determining factor in her self-estimation. A liability to shame reveals that we recognize the limitations of our own self-conception. Shame prevents us from ignoring our unflattering features that undermine our own positive self-estimation.

\section{The Traditional Definition}

I begin with a brief sketch of the traditional view of shame. The idea that we feel shame when and because we fail to live up to standards can be traced back to accounts offered by John Rawls and Gabriele Taylor. ${ }^{5}$ In $A$ Theory of Justice, Rawls claims that shame is broadly "painful, since it is the loss of a prized good" and when we experience shame, we suffer a blow

\footnotetext{
4 Nussbaum makes this observation (2004: 209-210). Deonna et. al. cite some psychological literature that support this link between shame and aggression (2012: 53-55).

5 Deigh suggests that both Rawls owes his account to Gerhart Piers and Milton Singer (225: 1983).
} 
to our self-esteem (1999: 388). ${ }^{6}$ Taylor distinguishes her account from Rawls' by arguing that shame is not a loss of self-esteem, but instead a loss of self-respect (1985: 78). According to Taylor, in feeling shame, the agent comes to see herself as inferior to what she had believed or hoped herself to be (1985: 64). The agent comes to hold this judgment because she sees herself as she is in the shameful situation in contrast with the person that she thought or hoped she was (1985: 66). For this reason, Taylor famously refers to shame as the "emotion of self-protection" (1985: 81). Our liability to shame is supposed to prevent us from failing to be the people we would like to be.

The advantages of defining shame as the painful experience of failing to live up to ideals or standards is that it fits comfortably in modern moral psychology. On this view, shame is an emotion of self-assessment that is an appropriate response to our failures of character (Rawls 1999: 388; Taylor 1985: 64; Mason 2010: 418; Deonna et. al., 2012: 177). Shame on this account can be positive and constructive because it lets us know that we have failed to live up to the ideals we value as part of a good character or a good life. The fear of shame helps keep us on the right track. If shame fulfills these functions, then it is "in all its occurrences is a moral emotion" (Taylor 1985: 77).

Several philosophers have accepted the traditional account outright. Although Kekes denies that shame is a moral emotion, he accepts that shame occurs "when we make a detached comparison between some aspect of ourselves and a standard we want to live up, and the result is that we find ourselves wanting" (1988: 284). While Manion denies that shame can always be a positive and constructive experience, she nonetheless accepts the traditional account (2002: 82-85). Mason accepts the traditional view in her work on shamelessness: she argues that shame occurs when one has "violated some legitimate ideal of character" (Mason 2010: 418). The most recent version of the traditional view has been provided by Deonna, Rodogno, and Ternoi (2012). Deonna et. al. modify both Rawls' and Taylor's account by defining shame not in terms of self-esteem or self-respect, but rather in terms of self-relevant values (2012: 99-100). The authors explain an agent's experience of shame as failing to live up to the values she sees as important to her sense of self: "Shame...consists in the subject's painful experience of one of her traits or behavior as reflecting her own incapacity to meet, even minimally, the demands cosubstanital with some of the values

More specifically, Rawls distinguishes between natural shame, which is an injury to our sense of self-esteem arising from a failure to exercise a certain excellence or virtue, and moral shame, which is a realization that one's actions have not properly expressed the virtues that are central to a good life (1999: 390). Both natural shame and moral shame arise from failures to live up to standards, so the distinction is not central to my discussion. 
to which she is attached" (Deonna et. al., 2012: 16-17) Although this view is not a simple reproduction of the traditional view, it shares the same core elements. ${ }^{7}$ Shame occurs when we fail to live up to norms, standards, or ideals that we care about.

\section{Feeling Shame and Being Bad}

There are cases of shame, however, that undermine the traditional definition. One of the most famous examples of shame comes from Sophocles' Ajax. At the beginning of the play, Ajax has made up his mind to murder Odysseus, Menelaus, and Agamemnon. To foil his plot, Athena tricks him into thinking that the animals in camp are his enemies. He slaughters them all, believing that he has killed the men who took his spoils. Once he realizes what he has done, he decides to take his own life from shame. What is puzzling about Ajax is that he has no trouble with the thought of becoming a murderer, but he cannot stand the thought of looking like a fool. He kills himself because he believes that his peers are taunting him for his foolishness, not for doing something wrong. In Ajax's mind, it is better to be hated as a murderer and traitor than to suffer the shame looking like a madman.

Perhaps Ajax's case is complicated since he was part of an honor culture. It is often argued that members of honor cultures have no way of assessing their worth apart from the judgments of their peers. ${ }^{8}$ Ajax could not survive disgrace because he would have no sense of self-respect left once the esteem of others was removed. Since Ajax is no longer esteemed by his comrades once he slaughters the cattle, he thinks his like life is no longer worth living. Yet surely Ajax would lose the esteem of his fellow soldiers if he really had killed Odysseus, Menelaus, and Agamemnon. The whole reason Athena inflicts madness upon him is to expose his plot, which she clearly thinks is underhanded and wrong. Even though honor cultures tended to be violent, outright murders were not esteemed by the honor

The authors argue that this wider conception of shame can, unlike the accounts of Rawls and Taylor, explain cases where an agent feels shame over something relatively mundane, such as when one realizes one has been walking around all day with a stain on one's shirt (Deonna et. al., 2012: 106). Such an instance is an occasion for shame, not because it is a blow to an agent's self-esteem or self-respect, but because the agent values keeping up a minimally decent appearance.

8 For instance, Taylor writes of honor cultures, "If public esteem is the sole value, to which whatever else may be valued is related as means to end, then it follows that where there is no public esteem, there is no value. . So there is nothing left, no inner quality or whatever, which could be judged to be of value in spite of the loss of public respect. Self-respect and public respect stand and fall together" (1985: 55). 
group. ${ }^{9}$ Ajax would be the object of disapproving judgments if he kills three of the most prominent Greek warriors just as he is the object of disapproval when he slaughters the cattle. Appeals to Greek honor culture cannot explain why Ajax is willing to live with the disapproving judgments in the former case, but not in the latter.

There are similar cases where people respond to feelings of shame with violence. Bigger Thomas in Richard Wright's Native Son feels shame when Mary Dalton is nice to him. ${ }^{10}$ He says she "responded to him as if he were human" (1998: 65). Mary's kind treatment only makes Bigger more selfconscious; he feels "naked and transparent" and acutely feels "the badge of shame that was attached to his black skin" (1998: 67). Later that evening, Bigger kills Mary accidentally, but he never thinks of this deed in those terms. Instead, he feels justified in murdering her because of the shame she made him feel. Despite that, he admits that she never meant to make him feel shame: "It seemed that her actions had evoked shame and fear in him. But even when he thought hard about it, it seemed impossible that they could have" (1998: 114). Even though he knows this, Bigger feels better after killing her. "And now that he had killed Mary he felt a lessening of tension in his muscles; he had shed an invisible burden he had long carried" (1998: 114). Mary Dalton treats Bigger with kindness and it makes him feel shame. When he kills her, his shame is alleviated.

A similar event occurs to Perry in Truman Capote's In Cold Blood. Dick, Perry's partner in crime, is convinced the Clutter family has a safe full of money in their house. When they rob the family, they discover there is no safe. Perry is looking for money in one of the rooms and finds a silver dollar hidden in a doll purse. He drops it and crawls on the floor to retrieve it: "It made me sick. I was disgusted. Dick, and all his talk about a rich man's safe, and here I am crawling on my belly to steal a child's silver dollar" (1993: 240). Perry grew up in poverty and looking for the silver dollar reminds him of that time in his life. Later Perry claims he had not planned to slit Mr. Clutter's throat; he was planning to pretend to in order to call Dick's bluff. But as he kneels down to threaten Mr. Clutter, "I thought of that goddamn dollar. Silver dollar. The shame. Disgust. . .But I didn't realize what I'd

9 William Ian Miller writes of honor cultures, "People were well aware that there was a poetics and a poetry of revenge, which was partly the reason it was the subject of the stories they most liked to tell. A man who went postal and took excessive revenge was understood to be acting not only without right but also without taste" (2007: 24). In honor cultures, revenge required a kind of equality. A more proper course of action would be to publicly challenge the offending parties in some way rather than secretly plotting to murder them.

10 Mary is surely overly familiar with him; she acts as though she and Bigger "live in the same world" (1998: 65). Bigger surely does find her behavior offensive, but this fact alone cannot explain why he feels shame in addition to being angry with her and why it is her kindness that engender these feelings. 
done until I heard the sound" (1993: 244). Thinking of the shame of crawling on the floor for a silver dollar leads Perry to suddenly stab Mr. Clutter. Even if we attribute Perry's original feelings of shame to the petty and lowly behavior of stealing a child's sliver dollar, his response to that shame is to do something much worse. The shame of crawling on the floor for a tiny amount of money leads him to murder a man he had not planned to kill.

In the cases above, the protagonists do something morally wrong in response to shame (Perry kills) or they prefer being bad to feeling shame (Bigger and Ajax). ${ }^{11}$ According to the traditional definition, the reason shame is so painful is because we realize our failures to embody the values we care about. Shame is thus supposed to cause us to act with restraint. As Taylor writes, shame "may prevent the person concerned from putting himself into a certain position or make him aware that he ought not be in the position he finds himself" (1985: 81). Alleviating shame is supposed to be accomplished by self-improvement. If shame is caused by a failure, it is "undone by proofs of defects made good" (Rawls 1999: 424). Getting over shame requires committing to living up to the value in the future. Likewise, according to Deonna et. al., shame will initiate positive self-reform since in shame "the subject is painfully revealed to herself as having an incapacity that she now has strong motivation to remedy" (2012: 177). In the cases I have described, shame inspires the opposite of self-improvement. Of course, one could claim that no one should behave this way in response to shame, but this claim does not answer the challenge. If the traditional definition claims that shame just is the painful feeling of not living up to an ideal, it cannot explain either why these people respond by doing something worse than failing to live up to an ideal and why doing something morally wrong then makes them feel better.

Philosophers have argued that shame is sometimes irrational, and it is possible that these cases can be explained by appeals to irrationality. Perhaps we could claim that the shame of Ajax, Bigger, and Perry is not

11 The cases I have described involve men and it should be noted that women do not frequently respond to shame with violence. There are, however, cases where women do respond this way. Ma Joad in The Grapes of Wrath, for instance, attacks a policeman with a frying pan after he calls her an "Okie" (2002: 213-214). When she recounts the event later, she describes her feelings as shame; the policeman makes her feel "mean" and "ashamed" (2002: 307). Even though Lucy Grealy does not respond with violence because of the shame she feels about her abnormal face, she does respond with hate: "I hated Danny in my orchestra class because I had a crush on him and I knew he would never have a crush on me. . Every time I felt hatred or any other 'bad' thought, I shooed it away with the broom of spiritual truisms. But the more I tried to negate my feelings, the more they crowded in" (2003: 181). Feelings of shame are of course influenced by social forces: since women are socialized not to be aggressive in general, violent responses to shame will be less common among them. But as Lucy's case illustrates, feelings of anger or hate pose the same problem for the traditional account. I am grateful to an anonymous reviewer for asking me to clarify this point. 
"properly focused" shame (Mason 2010: 418). Properly focused shame occurs when (1) we hold ourselves responsible for our failure and (2) when the norm to which we respond is a legitimate one (Mason 2010: 418). In this way, we might claim that Ajax's shame, for instance, is irrational because he was not responsible for his actions (since Athena made him temporarily insane). Another way to explain irrational shame is to think of it as "false shame" (Taylor 1995: 163). Genuine shame is the moral kind that occurs when we fail to live up to our ideals, but false shame occurs when we have standards or norms imposed upon us for a brief period (1995: 163). Deonna et. al. classify the above cases as those of shame-prone individuals. A shame-prone person has a "maladaptive self-image" (2012: 161). Shame-prone individuals are more apt to respond with aggression than those who are not, but this is an issue with shame-proneness and not with shame (2012: 160-161). Shame-proneness stems from an unhealthy self-image and is thus irrational. If the shame in the cases above is improperly focused, false, or attributable to shame-proneness, then perhaps the traditional view need not be troubled by these examples.

First, even if the above responses are irrational, it does not automatically disqualify them from conceptual analysis. As Deigh writes, we have no reason to "regard the class of rational or reasonable experiences of a given emotion as privileged for the purposes of conceptual inquiry" (1983: 237). Removing cases of so-called irrational shame from the analysis of the emotion is predicated on the assumption that thinking about or trying to understand irrational instances of an emotion is philosophically fruitless. But why should this be the case? Surely we can learn something about guilt, for example, by trying to understand why it often persists even when agents admit that they've done nothing wrong or when they know they made the best all-things-considered choice. One of the most philosophically rich analyses of guilt is Williams' "agent-regret" from "Moral Luck," in which he denies the long-held premise that we can only feel guilt for voluntary actions (1981). ${ }^{12}$ Prior to Williams' arguments, it would be normal to claim that the lorry-driver's guilt for accidentally hitting a child was an irrational emotion. As Williams' arguments about guilt demonstrate, rather than thinking the cases are problematic, it may be that our traditional definition is problematic.

I want to suggest, however, that there is no reason to think that violent responses to feelings of shame are irrational. The temptation to think that the cases above are irrational is a form of what D'Arms and Jacobson have called "moralism" (2000: 75). As D'Arms and Jacobson write, “[W]hen an

Williams goes not use the term 'guilt' but rather 'agent-regret.' His larger point, however, is that we should feel badly in some way even for actions that cause harm to others even if we do not intend those actions. 
emotion seems morally incorrigible, philosophers are tempted to convict it of some gross error" (2000: 75). The authors give the example of jealousy: a traditional way of understanding jealousy is that it is an emotion that wrongly regards people as possessions. For this reason, philosophers often claim that it is irrational and we ought not feel it (2000: 75). According to the authors, philosophers conflate two senses in which we 'ought not' feel certain emotions: 'ought not' can mean that an emotion is "inappropriate" or bad to feel, or it can mean that an emotion is "unfitting" or irrational to feel (2000: 68). When an emotion is morally wrong to feel, philosophers are likely to be deem it unfitting and thus irrational. The authors argue, however, that an emotion can be fitting even if it is morally wrong to feel.

To illustrate the difference between "unfitting" and "inappropriate" suppose you are envious of a friend because she is going camping in the woods this weekend. You hate camping, but you are nonetheless envious of her (2000: 73). Here, your envy is unfitting - it is irrational to be envious of someone for having something that you don't care about having for yourself. Now suppose your friend has a beach house rather than a camping trip. In this case, she does have something you want. It makes sense that you would be envious since we are envious of people for having things that we desire (2000: 71). If you were envious in this case, you might be wicked or not virtuous and you could be morally criticized on account of your envy. But your emotion would not be irrational. A third party might, for instance, try to console you by saying, "It's only natural that you're envious, just don't let it get the better of you." To claim that your envy is "only natural" is precisely to acknowledge that it makes sense to feel even though it might be morally unsavory.

Because the agents in the above cases morally ought not feel way they do (it is wrong to be violent), it is tempting to conclude the way they feel must be irrational. Deonna et. al. claim, for instance, that if someone responds to feelings of shame with anger or violence, then she must have a maladaptive self-image. But just because shame-prone individuals are more likely to respond to shame with aggression, it does not follow that anyone who responds to shame with aggression is thus shame-prone. This conclusion is only justified if we think that episodes of shame could not cause aggression in a person who is not shame-prone, but there is no reason to hold this without further argument to support it. The agents in the above scenarios ought not respond to their shame with violence, but a morally inappropriate reaction is not automatically an irrational reaction. Notice that we can explain inappropriate instances of other emotions, such as guilt, without appealing to "false" guilt or "guilt-prone" people. Suppose I want to go on vacation, but I feel guilty because I worry that I haven't gotten enough work done. Someone could point out to me that I've been working very hard for months and that I have accomplished a lot, and so there is no 
need for me to feel guilty. Even though I have no reason to feel guilty, my guilt is intelligible because I believe that I am not doing what I should be doing. My guilt might be inappropriate, but, like the case of envy above, it is not mysterious. The reactions in the cases of shame above, however, are mysterious on the traditional view. If failing to live up to ideals is supposed to explain why Ajax, Bigger, and Perry feel shame in the first place, we cannot explain why they respond by doing something that counts as falling further from those ideals.

Another possibility is that these are examples of humiliation rather than shame. Deonna et. al. employ this strategy. They argue that humiliation rather than shame is closely connected to violence and that we ought not conflate the two emotions (2012: 156-159). On their view, humiliation has two features that shame does not have: humiliation "arises from perceived demeaning treatment by others" and this treatment is "construed as undeserved in the circumstances" (2012: 118). These two features are meant to show a closer link between humiliation and aggression, since "being aware that others are treating us unjustly... is obviously an evaluation closely connected with anger and/or indignation" (2012: 160). First, the description of humiliation offered here does not fit two of the cases I have described. Neither Bigger nor Perry are subject to perceived demeaning treatment from others. Mary Dalton is nice to Bigger and he even acknowledges that, but her actions make him feel shame nonetheless. Perry is alone in the room while he's searching for the silver dollar; it's his decision to crawl on the floor to get it. Thus the connection between violence and shame appears even when perceived ill treatment from others is absent. Further, the claim that the emotion in the above examples has to be humiliation simply because the agents respond to it with violence begs the question against anyone who denies that shame is the painful experience of living up to values. In each of the works, the emotions of the characters are described as shame; why should we be skeptical just because their shame does not seem to fit the model we have constructed? Finally, the claim that these cases are humiliation rather than shame cannot explain the apparent ease with which the two experiences are conflated. As Deonna et. al. point out, several psychologists and philosophers mistake humiliation for shame (2012: 156157). If the two experiences are as different as Deonna et. al. claim, why is it so easy to mix them up? Even if there is a distinction between shame and humiliation, they have to be more similar than Deonna et. al. contend if philosophers, psychologists, and people having the experience slide between them so easily.

Although the traditional definition of shame has been dominant in the literature, it is worth noting that there are philosophers who have offered different accounts of shame that might make more sense of the cases I describe. These accounts focus on the public nature of the norms and ideals 
that we fail to live up to. ${ }^{13}$ While these accounts still accept the basic notion that shame is about failing to live up to ideals, they emphasize the point that the ideals are not those of the agent who feels shame, but rather values of the group to which the agent belongs. Gibbard explains shame in terms of "adaptive syndromes" or responses to threats in our standing in networks of social cooperation (1990: 138). On his account, we feel shame when we display a "lack of powers or resources" to engage in social reciprocity (1990: 138). In a similar vein, Maibom argues that shame develops from a more primitive submission response that we find in non-human animals (2010: 578). Human shame is "an implicit acknowledgment of a demand to live in accordance with public norms and standards" (2010: 587). We "submit" in other words to abide by the norms that govern social life and practice.

Can these naturalistic accounts explain violence and shame? Violent responses to shame might be ways we "display our powers" in order convince others that we do have the standing a strength to reciprocate (Gibbard 1990: 139). But it is not clear why violence would accomplish this: aggressive behavior does not send a message of reciprocity. Gibbard later writes that the main function of shame is to show "deference and a willingness to accept the...terms of cooperation" (1990: 298). The naturalistic account of shame more often frames it in terms of appeasement (Maibom 2010: 585). In other words, shame is an emotion that both responds to the disapproval of others (usually others from a dominant or powerful group) and communicates to those others that the agent recognizes she has violated their norms. Although appeasement can explain common bodily responses to shame like hiding or covering up, it cannot explain angry or violent reactions. More problematic, however, is that shame is meant to indicate that agents have agreed or internalized public norms and standards (Maibom 2010: 587). Again, the aggressive reactions fly in the face of this idea: a violent person does not show an implicit acceptance of the norms of public life.

The accounts of shame that focus on norms and standards-be they the individual's own values or public norms - cannot explain why agents are tempted to respond to shame by doing something wrong. Agents seem to be more comfortable killing than feeling shame, and the claim that shame is the painful experience of failing to live up to a standard cannot make sense of this response. It is my aim in what follows to sketch a new definition of shame that can explain the cases above. reason we are susceptible to shame is because we see ourselves as members of a group with values and expectations. But this account cannot explain violent responses to shame: doing something aggressive would surely not send the message to others that we recognize the value of their judgments. That said, I draw on the accounts from Williams and Calhoun later in the paper. 


\section{A New Account of Shame}

I will argue that an agent feels shame when some aspect of her identity becomes prominent or revealed in the shameful moment and that she feels that this thing defines her as a whole. ${ }^{14}$ That is, in episodes of shame she feels defined by, reduced to, or totalized by some feature of herself. ${ }^{15}$ I take this defining feature of shame to be necessary rather than sufficient. In other words, someone may find herself in these circumstances and feel something other than shame. My contention is that when an agent reports feeling shame, this feature will be present in the experience. Similarly, if an agent does not yet feel shame, but fears it, it is because she fears that some aspect of herself will define her.

To illustrate this explanation of shame, consider a scene from Lucy Grealy's Autobiography of a Face. Lucy had cancer as a child and multiple surgeries have left her face disfigured. After yet another reconstructive surgery, she unexpectedly catches sight of herself in a dressing room mirror: "This reversed image of myself was the true image, the way other people saw me. I felt like such a fool. I'd been walking around with the secret notion of promised beauty, and here was the reality" (2003: 185). After this experience, she begins having "overwhelming attacks of shame at unpredictable intervals" (2003: 185). She describes one of these attacks, which occurs when she is riding a horse in a local schooling show:

14 J. David Velleman (2001) has articulated a view like this and my account draws inspiration from his. His account relies heavily on the thought that shameful things undermine one's self-presentation, which "threatens one's social recognition as a self-presenting person” (2001: 50). Although I do not wish to deny Velleman's conclusion, I do not think it is essential to explaining shame. The fact that shameful things undermine our self-conception is I think enough to explain shame without importing the social recognition of others. Velleman also does not wish to claim that shame is a moral emotion, but I do.

Here I draw on Sartre's account of shame in Being and Nothingness (1992: 347-387). "Pure shame is not a feeling of being this or that guilty object, but in general of being an object; that is, of recognizing myself in this degraded, fixed, dependent being which I am for the Other" (1992: 384 emphasis original). Zahavi seems to hold that for Sartre we must accept the judgment of the other whether that judgment is positive or negative: "To feel shame is - if ever so fleetingly - to accept the other's evaluation" (2010: 216). Likewise he writes, "To feel ashamed is to feel unworthy, is to feel that the negative assessment of the other is deserved" (2010: 218). I think this is mistaken. It does not fit with Sartre's claim that we cannot experience the qualities that others attribute to us as ours. He writes, "I cannot live them as my own realities. If the Other confers them on me, they are admitted by what I am for-myself' (1992: 366). The feeling of being totalized or reduced to some aspect of ourselves is all that is required and we can feel this way without accepting the content of the judgment. In my view, Buss' reconstruction of Sartre's view is more accurate. She describes shame as "being conscious of oneself as an object of appraisal for another subject" (1999: 526). Consciousness of being an object is the important aspect of Sartre's account for my view. 
"In practices, I always wore a helmet with my hair hanging loose beneath it, but etiquette required that during shows my hair be tucked neatly up beneath the helmet, out of sight...This simple act of lifting my hair and exposing my face was among the hardest things I ever had to do...I would have gladly undergone any amount of physical pain to keep my hair down. No one at the show grounds ever commented to me about it, and certainly no one there was going to make fun of me, but I was beyond that point. By then I was perfectly capable of doing it all by myself" (2003: 186)

Lucy's feelings of shame are often the kind we point to as examples of irrational shame: she ought not feel shame about her face because there is nothing wrong with having a face that is shaped differently than other people's faces. As I have argued above, however, the claim that she ought not to feel shame does not entail that her shame is irrational. And to claim that Lucy's shame is rational is not to claim that she ought to feel it. We can explain why people feel certain emotions without endorsing instances of those emotions.

Moreover, it is patronizing to people who experience this kind of shame to claim that it is irrational. Notice what is entailed here: Lucy must feel shame because she falsely believes that she can control her appearance and thus live up to a standard of beauty, or she feels shame because she falsely believes that being beautiful is a norm to which she must live up. Deonna et. al. make this argument about cases where agents feel shame about their appearance:

"If the principle according to which it is rational to impose on ourselves demands only if we are capable of honoring those demands holds true, there is a sense in which it is irrational to persist in perceiving ourselves as required to exemplify the relevant value when this is simply impossible" (2012: 111).

As Calhoun points out, however, these claims "encourage us to find fault with ashamed people" (2004: 137). Because the traditional way of understanding shame is about failing to live up to values, we are forced to claim that agents who experience shame about their faces have misguided values and false beliefs. A different account of shame could explain them in a way that does not require attributing mistaken values to agents who feel this way.

If shame is the experience of feeling defined, reduced to, or totalized by some feature of ourselves, Lucy's shame does make sense. She feels as though her face makes up the whole of her identity. This need not be something she accepts or endorses; she only needs to see it as a possibility. She can feel as though her face overshadows the rest of her even if no others have made her feel that way, as her experience in the horse show illustrates. Her shame is due to that fact that she feels as though she is just this face. 
Experiences of shame thus involve a tension between our identity and our self-conception.

Self-conception, as I understand it, is akin to what Velleman calls "selfimage," which is how we represent to ourselves the person we take ourselves to be (2006: 3). But our identities extend beyond what we represent to ourselves. An agent's identity is who she is in a broader sense and can include things that fall outside of her self-conception. ${ }^{16}$ Lucy's experience of shame illustrates the tension between how she sees herself and who she is in a broader sense. Her shame arises because in the mirror she suddenly sees her face not the way she represents it to herself, but the way it might look to someone else. She feels "like a fool" because her self-conception presented her face in one way, but the mirror undermines that self-conception. As Velleman points out, someone with a physical abnormality "may experience shame if he senses that he is perceived solely in terms of his deformity, to the exclusion of any self-definition on his part" (2001: 45). Shame arises because even though Lucy does not want her face to define her, she still realizes that her face is part of who she is. The inability to disavow that aspect of ourselves by which we feel defined explains why shame makes us feel so powerless. The thing that causes me shame both overshadows me and yet is me.

This tension between identity and self-conception is a feature of most of the paradigmatic cases of shame. Many philosophers have observed that shame arises in response to those aspects of ourselves over which we have very limited control (Deigh 1983; Kekes 1988; D'Arms and Jacobson 2000; Nussbaum 2004; Mason 2010; Maibom 2010; Deonna et. al., 2012). Our bodies, our intelligence, our grace (or lack there of), our families, and our socioeconomic status are all things over which we have little influence. And yet these things are-for better or worse-ours. The shame that we feel about these aspects of our identities does not stem from the fact that we falsely believe we are responsible for them and thus failing to live up to ideals. It stems from the fact that they compete with our self-conception in comprising who we are. Lucy wants to see her face as "normal," but the reflection in the mirror both undermines that representation and yet confirms that the face in the mirror is her face. This feature of shame is also present in cases where agents feel shame even when their bodies are "normal" or even attractive. Scheler provides the example of an artist's model who feels shame when she realizes she has become the object of the artist's sexual

16 Providing a full account of the concept of identity would be a project in its own right. I do not mean to make substantive claims about the nature of identity. It is enough for my account that an agent's identity is wider or broader than her self-conception. Calhoun's (2004) discussion of identity illuminates this more fully. 
attention. ${ }^{17}$ The traditional view may explain her shame in terms of her values of modesty or privacy, but since she is posing nude, such appeals seem misplaced. My account can accommodate this case because the model feels overshadowed by a particular aspect of herself, namely her sexuality. The model feels defined in the eyes of the artist by her body in the much the same way that Lucy feels defined by her face. The only difference is that the artist is attracted to her body while most others are not attracted to Lucy's face. ${ }^{18}$

Several philosophers have also noted that women and persons of color report more feelings of shame than white men. Bartky (1990), Manion (2003) and Calhoun (2004) claim that women tend to feel more shame than men, and Piper provides a similar example of what she calls her own "groundless shame" for refusing to pass as white (1996: 547). Bigger Thomas says that there is "a badge of shame" attached to his black skin (1998: 67). Some philosophers think that in order to feel shame, an agent has to accept the judgment that others make about her: if she feels ashamed because others think she is a fool, it has to be because she believes herself to be a fool or that she cares that others thinks she is a fool (Kekes 1988; Deonna et. al., 2012). But it is problematic to claim that women and persons of color feel shame because they secretly feel like failures because of their biological sex or their skin color (Calhoun 2004: 137). We need not endorse or condone these feelings of shame, but we ought to be able to explain them, given how prominent and powerful they often are. If we think of shame as feeling defined by some aspect of our identities, the fact that women and people of color feel more shame is understandable (again, not good or appropriate). They are more likely to feel overshadowed by some aspect of themselves. Women and people of color are often thought of as a group rather than as individuals and others attribute thoughts, feelings, and behaviors to them in light of their sex or their skin color. Feeling as though one's identity can be "read off" of one's skin color or sex understandably makes one feel totalized by one's skin color or sex.

My account of shame also explains the phenomenology of shame. One of the most common aspects of episodes of shame is feeling "small" or "shrunken" (Deonna et. al., 2012: 108). On my account, this phenomenology is explained because we do feel small or shrunken - the self with which I identify is overshadowed by whatever aspect of myself becomes prominent in the shameful episode. The feeling of smallness is the feeling of our

Taylor explains the example and my account of it comes from her text (1985: 61).

18 Notice that the model does not need to feel badly about her sexuality to feel shame. She only needs to feel as though it is overshadowing her own self-conception. Calhoun explains: "Even if in one's own view one has nothing to be ashamed of, one may nevertheless have reason to feel shamed" (2004: 143, emphasis original). 
self-conception being dwarfed by the aspect of our identities that inspires our shame. Although that thing may loom large in the experience, our selfconception is what feels reduced or shrunken. The feeling of smallness is thus the feeling of being overshadowed by that which causes shame. Likewise, shame's physical responses reflect this feeling of being overshadowed. Common reactions to shame like covering one's face and body and wanting to hide are indicative of our desire to hide or cover that by which we feel defined. If we can remove ourselves from sight, that which defines us in the shameful episode will be hidden also. Once we feel defined or overshadowed by some aspect of ourselves, we often fear this reduction will be permanent, especially in the eyes of those who witness our shame. After our shameful incidents, we often think, "I can never go back there again" or, "I can never face them again." We feel as though our shame will haunt us forever. What we fear is that others will never be able to look past that aspect of ourselves that causes our shame and so will never see us as we want to be seen.

One of the most confounding features of shame has been the role the audience plays in the experience. Some philosophers have argued that the audience is central if not essential to feelings of shame: we feel shame when we are seen or judged by others (Deigh 1983; Kekes 1988; Gibbard 1990; Williams 1993; Wollheim 1999; Maibom 2010). By contrast, other philosophers have pointed out that we can feel shame when we are alone, and so focusing on the need for an audience is misguided (Taylor 1985; Mason 2010; Deonna et. al., 2012). Even if an audience is not essential to shame, the fact that we feel shame most acutely in front of others is undeniable. The role of others in episodes of shame highlights the tension between self-conception and identity. When I interact with others, they can come to conclusions about who and what I am independently of who I take myself to be. Notice we often fear that others will draw conclusions about us regardless of how we see ourselves: a person who is shy might worry that others attribute her silence to snobbishness. Even if she does not agree with those conclusions, she still has to contend with them because others will interact with her based on who they take her to be. This trait that she recognizes as hers can come across to others in ways she does not want it to. Because others will draw conclusions about her based on what they encounter, they can form a conception of her identity that is independent of how she sees herself. Lucy may feel as though others only see her face when they look at her; it is the thing people will remember most about her. But we can feel shame independently of how others behave toward us: when Lucy has to put her hair up in the horse show, the fact that her face is clearly visible is enough to cause her feelings of shame. Even though the presence of an audience is not central to my account of shame, it can explain why we so acutely feel shame before others. 
The paradigmatic cases of shame I have described here are often called "natural shame" whereas the cases that are most familiar to the traditional view are labeled "moral shame" (Rawls, 1999; Manion 2003; Mason 2010). Moral shame is the kind where we fail to live up to ideals and the rest is natural shame. ${ }^{19}$ This distinction seems to arise only to explain why we feel shame about vastly different things. Notice, however, that no other moral emotion is treated this way: no one advocates for "natural" and "moral" resentment or guilt. On my view, there is no need to divide shame into kinds because the account I offer here can explain the cases of so-called moral shame without reference to a failure to live up to ideals. Mason claims an agent might feel ashamed for stealing a candy bar and points out that the agent will feel shame about the kind of person she is: "How could I have been so petty? So low? So deceptive?" (2009: 419). Notice that Mason's agent is asking questions of herself: how could I have done this? The shame she feels is not because she has failed to live up to her values, but because in spite of how she represented moral character to herself, she clearly was capable of doing something she thought she would never do. Her shame about stealing the candy is due to the fact that this act now looms large in her self-estimation: she is only the petty thief in spite of what she thought about herself. Murphy's example is similar: as a young boy he experiences shame when he callously rejects a baseball glove his father gives him (1999: 339). He wonders how he could be "the kind of person who could have been so insensitive" (1999: 340). His wonderment at his own callousness is due to the fact that he did not see himself as someone capable of ingratitude. But his dismissal of the baseball glove has revealed to him that he indeed could be that sort of person in spite of how he represented his own character to himself. His shame arises because although he thought of himself as a grateful son, his action now leads him to think that he might not be that kind of son after all.

Finally, the account I offer here can explain why agents respond to shame with violence. I have argued that the traditional account of shame as failing to live up to virtues or values struggles to explain these cases because shame defined this way is supposed to inspire self-improvement (Taylor 1985: 81; Rawls 1999: 424; Deonna et. al., 2012: 177). But why can't the naturalistic account accept the conclusion I have offered that violence alleviates feelings of shame, since this account makes no claims about virtues? As Gibbard claims, shame might be a form of "displaying our powers" (1990: 139). But the naturalistic account concludes that shame is supposed to show an agent's commitment to reciprocity and internalizing public standards. Both Gibbard and Maibom argue that shame causes us to

19

Some philosophers have denied this distinction claiming that there is no reason to divide shame into kinds (Taylor 1985; Deonna et. al., 2012). 
submit to the ideals of the dominant group (1990: 298; 2010: 587). Acts of violence, however, are not forms of submission. Violent responses to shame would be a challenge to the ideals of the dominant group. If shame just is the emotional signifier that the agent has accepted the ideals of the dominant group, then still violence does not make sense as a response. If feelings of shame are supposed to cause submission, then it is unclear why agents would respond to shame by doing the opposite. Additionally, if shame is meant to inspire reciprocity or appeasement, agents who respond to feelings of shame with violence should feel more shame rather than less because they are challenging the dominant group's values. On the traditional account, shame is meant inspire self-improvement and on the naturalistic account shame is meant to inspire appeasement. But violent responses to shame do neither of these things.

On my view, we respond to shame with violence because it allows us to once again feel defined by our self-conception rather than those aspects of ourselves that fall outside of it. The clearest illustration of this kind of response occurs in the film The Elephant Man. To hide his abnormal face, John Merrick wears a cloth mask in public. While he is at a train station, a group of people begins to follow him and chase him down. His mask comes off and the crowd gathers around to stare and gasp. He suddenly shouts at them, "I am not an animal!" His cry is an act of self-assertion. He feels totalized by or reduced to his face and he shouts in order to "speak louder" than his appearance. He could have just as easily shouted, "I am not my face!" John has no control over his appearance, and as I previously mentioned, many of the things about which we feel shame are not under our immediate control. Our bodies, our sexuality, and our socioeconomic statuses are all rich targets for shame that are a part of our identity even though we do not choose them. Shame makes us feel that we are not in control of who we are: parts of my identity define me independently of how I want to define myself. One of the ways of alleviating shame is to do something that regains a sense of control. We try to hide, cover ourselves, or get away from the situation, and these actions can help us regain feelings of control because we remove from sight the thing we experience as shameful. Violence, anger, and aggression can accomplish the same goal. At first this looks puzzling because it seems that we might be equally reduced to or totalized by our acts of violence or aggression as much as our faces or bodies. Indeed, agents often do feel shame for doing something violent: imagine, for instance, that I kick my dog out of anger and I feel shame as a result. The difference between cases like this one and the cases of Ajax, Bigger, and Perry is that the source of the violence is different. When I kick my dog out of anger, I am ashamed of my cruelty. Like Mason's case of stealing the candy, I am surprised that I am capable of doing something so 
mean. I might ask myself how I could have done such a thing. Here I experience my cruelty as a feature of my identity, but not my self-conception.

The violence in the cases I have described, however, is an act of selfassertion. I have claimed that shame arises out of a break between one's self-conception and one's identity. In shame we feel that aspects of our identity overshadow our self-conception. My sense of myself as an agent is closely connected to my self-conception. That is, one of the primary ways I think of myself is as an agent: one who chooses, acts, and makes decisions. Since my sense of my own agency is a large part of my selfconception, when I am seen as an agent, I feel as though my self-conception (not the parts of my identity that fall outside of it) is determining who I am. In shame, we are reduced to some feature of our identity that we experience as fixed, but an act of violence is something we do-it is part of our agency and thus a part of our self-conception. Even though others respond negatively to an agent who does violent things, they are responding to that person as an agent rather than as the possessor of some shameful feature.

We can see this by examining how the responses others have to those in shameful moments contrast with the responses others usually have toward people who do violence. In shameful moments, others typically respond to us with laughter, disgust, or dismissal. Ajax feels shame because he believes slaughtering the cattle has made him look like a fool and that his fellow warriors are laughing at him. Perry also feels foolish crawling on the floor for the silver dollar. Lucy believes that people find her face disgusting; she is convinced that people are staring at her at the horse show. Laughing at or staring at someone is to see her as the object of amusement or fascination. But the violent person is the object of emotions such as resentment or hatred. $^{20}$ As several moral philosophers have argued, emotions such as resentment and hatred presuppose that those to whom they are directed are responsible agents (Murphy and Hampton 1988; Wallace 1994; Scanlon 1998; Strawson 2003; Darwall 2006). That is, we respond to violence with resentment because we assume the agent willfully does the violent act. Our feelings of resentment are often mitigated if we find out that some perpetrator of violence was not in control of her actions. Ajax's case makes this clear: Ajax is pitied rather than resented because he was mad when he slaughtered the cattle. Absent these mitigating factors, in resenting others for their acts of violence, we presume that they do violence willfully. If I do something violent and others respond to me with resentment, they see me as an agent and not as the possessor of some shameful feature. If others see me as an agent, then because my agency is a large part of my self-conmon. 
ception, they are now seeing me in terms of how I see myself. Becoming the object of resentment by doing something violent helps us to regain the feeling of control we lose in shame because we once again feel that our self-conception determines who we are. Others surely respond negatively to me as the violent agent, but they are no longer seeing me as an object of amusement or fascination. What we seek in shame is not approval, but recognition: the Elephant Man shouts at the crowd because he wants them to see him, not his face. Violence gains us that recognition because in asserting our agency, we assert our self-conception. Ajax would not have been esteemed as a murderer, but he would have been seen as an agent of his own making instead of a crazed madman. Bigger feels better after murdering Mary because although he will be resented, he is defined by his violence (something he does) and not by his race (something he is). Perry would rather kill Mr. Clutter and be resented for it rather than feel reduced to his childhood poverty that he wishes he could forget.

Violence of course need not be the only response that allows us to reassert our agency. Notice, for example, that Hester Prynne in The Scarlett Letter overcomes her shame through acts of kindness. She is likewise regaining a feeling of control by asserting her self-conception as an agent rather than as the passive recipient of contempt from the townspeople (2004). ${ }^{21}$ Even though there are other ways to assert one's agency, acts of violence are especially tempting responses to shame because the lack of control we experience in shame makes us feel powerless. And although it is morally inappropriate, violence makes us feel powerful. Violence turns the tables in shame: in the moment of shame I was made to feel powerless, and now as a violent agent others are powerless before me. We need not condone these violent responses or think they are good or appropriate. My account of shame can, however, explain why violence is a tempting response and why violence alleviates feelings of shame rather than making them worse.

\section{The Moral Standing of Shame}

The account I have offered here can explain some of the most common features of shame, and it can accommodate the so-called moral and non-moral cases. It can also account for violent reactions to shame. One might object, however, that successful conceptual analysis fails to show how shame can be morally valuable. The advantage of the traditional definition of shame as failing to live up to a standard or ideal is that it shows how shame can fit comfortably in our modern moral lives. As such, it appears that my account

21 Prynne's case is complex because she is the subject of public shaming and it is unclear the degree to which she actually experiences the emotions of shame. But her kindness does force the people of the town to see her differently and it does allow her to forge a new sense of self. 
provides a more complete conceptual analysis at the cost of the conclusion that shame can be a valuable moral emotion. If I am right about shame, it seems that shame has no moral value at all: we ought never feel defined by some aspect of ourselves that lies outside our self-conception. I want to conclude by arguing that my account of shame does have moral value.

Moral philosophers usually frame discussions of shame's moral status by asking whether or not we ought (morally) to feel episodes of shame. Guilt functions this way: there are certain instances where one ought to feel guilt and, if one does not, one can be morally criticized for not feeling it. At first glance, shame seems to fit this model. Suppose we catch someone spreading gossip and we say to her, "You should be ashamed of yourself." But cases like this are less illustrative than it might seem. Most of the time telling someone she should be ashamed simply means that she should feel badly about herself for what she has done-she should have a lower opinion of herself in light of her actions. But thinking less of herself does not require shame at all: we can be self-critical in all sorts of ways without feeling shame. I think framing the discussion of shame's moral value in terms of when we should feel it is ultimately misleading. Instead, I want to examine the question of shame's moral status not by asking when we should feel shame, but rather whether a liability to shame is morally valuable.

To illustrate what a liability to an emotion is, take grief as a possible example. ${ }^{22}$ Being liable to grief reflects implicit commitments about our relations with others. If we are liable to grief it shows that we are able to feel deeply for others and give them special standing in our lives. To no longer be liable to such an emotion would not leave untouched the commitments and attitudes implicit in that liability. If I am not susceptible to grief, it calls into question the depth of my feelings for others. Notice, however, that even if a liability to grief reveals valuable commitments, it does not then mean that grief is automatically morally good in a given instance and that we should prescribe it. It simply means that maintaining those commitments we value requires a continuing liability to grief, even if it is painful. Similarly, the moral value of shame can be seen most clearly by considering what it would be like to no longer possess a liability to it. Even philosophers who do not see the value of shame agree that there is something wrong with being shameless. ${ }^{23}$ What might be bad about shamelessness?

I want to suggest that what is bad about shamelessness is that it reveals an agent's failure to recognize the limitations of her own self-conception. As Buss writes, "For if [people] were incapable of shame- they were, as we say,

I do not mean to claim that grief is in fact a moral emotion, although it certainly may be. I think the way in which we might evaluate it (determining what it reveals rather than when we ought to feel it) would remain the same in either case. 
'shameless' - they would be incapable of recognizing that their own point of view is not the only one that is relevant" (1999: 530). What makes shame valuable is that having a liability to it means that we do not take our own points of view as the only important ones. The shameless person suffers from a kind of imperviousness. Recall Williams' example of the man who believes he is just while everyone treats him as though he is unjust. Williams writes that there is no way to tell "whether he is solitary bearer of true justice or a deluded crank" (1993: 99). Williams' point is that who we are is not determined solely by how we think of ourselves and what we take our own values to be. Just because I think that I am a just person does not mean that I am just, and the potential for me to deceive myself about who I am is high. ${ }^{24}$ I like to think that I am just person and I am prone to rationalize away any evidence to the contrary. The more authoritative I think my self-conception is, the more prone I am to overlook things that do not fit with it.

A liability to shame prevents us from taking the way we see ourselves to be the primary authority in our self-estimation. Feelings of shame arise when we feel defined by some aspect of our identity that is not part of how we see ourselves. Even though that part of our identity is not part of our self-conception, we feel shame because we still acknowledge it as ours. The shame I feel about my low-class family, for example, indicates that I still see them as mine; I claim them even though they undermine the view that I have of myself as a high-class person. But I can only feel defined by my family if I first accept that parts of my identity that are outside of my selfconception are still part of me. My family is still mine, which means I have to contend with the fact that my relationship to them paints me in a different light than the light in which I paint myself.

The shameless person, by contrast, does not accept that things that fall outside of her self-conception are hers whether they match up with that self-conception or not. The flatterer is shameless because she does not see her flattery as ingratiating as long as she presents it to herself with a positive spin. The self-promoter is shameless when she does not see her actions as opportunistic because she presents them to herself as savvy. In order to see this, both the flatterer and the self-promoter would have to take seriously the thought that their own views of themselves might not determine how they should assess themselves. As it stands, they are impervious to the thought that their behavior might not be as innocent as they see it. The danger of not being liable to shame is thus the danger of being the deluded crank. Shame unsettles the authority of our own self-conception. We need shame because of our all-too prevalent tendency to evaluate ourselves positively when we think we're doing a fine job of things. Contrary to the traditional view of shame, it is not an emotion of self-protection. Shame is an 
emotion that prevents self-inflation, not because it is morally good to judge ourselves lowly or poorly, but because a liability to it requires that we recognize that we are not always the people we take ourselves to be.

One might object that a liability to shame means that we will end up feeling it for things that we ought not feel shame about. It is common to think that, while I should feel shame about self-promotion, I should not feel shame about my crooked nose. But what exactly do we mean by the claim that I should not feel shame about my nose? I have argued that we do not mean that shame is irrational-shame is a rational response in this case because I feel as though my nose defines me and overshadows my own self-conception. On my view, when we say that I ought not to feel shame about my crooked nose, what we really mean is that I ought not feel defined by my nose. My crooked nose is not something that should factor into my self-estimation. Yet this claim is not an indictment of shame, but instead of the fact that I am (and others might be) making judgments about who I am based on something that is not representative of who I am-shame is the symptom, not the disease. The fact that I should not feel shame about my crooked nose, however, does not make my liability to shame any less morally valuable. We can distinguish the moral value of an emotion from the moral value of its particular episodes. We surely judge that some instances of an emotion are inappropriate without then claiming that the emotion as a whole has no moral value. Guilt clearly functions this way: the fact that there are inappropriate instances of guilt does not cast doubt on the importance of guilt on the whole. A world where people never felt defined by their bodies or their social standing might be a better world, but such a world would not necessarily be a world without any shame.

Moral philosophers are faced with a two-fold challenge in thinking about our moral emotions. We seek to explain their place in moral psychology while at the same time ensuring that our conceptual analysis is familiar to ordinary experiences of that emotion. While the traditional view of shame achieves the former, it does not achieve the latter. I have argued that shame has little to do with failing to live up to values. It is rather the experience of the tension between our identity and our self-conception. Even though my account of shame can explain the unsavory features of shame, it does not mean that this experience has no moral value. A liability to shame is important because it requires an acknowledgement that our own self-conception is not the determining factor in our self-estimation. We feel shame because we are not always who we take ourselves to be. ${ }^{25}$ 


\section{References}

Bartky, Sandra Lee. (1990) "Shame and Gender," in Femininity and Domination: Studies in the Phenomenology of Oppression (New York: Routledge).

Buss, Sarah. (1999) "Respect for Persons," Canadian Journal of Philosophy 29, pp. 517-550.

Calhoun, Cheshire. (2004) "An Apology for Moral Shame," The Journal of Political Philosophy 12, pp. 127-146.

Capote, Truman. (1993) In Cold Blood (New York: Vintage Books).

D’Arms, Justin and Jacobson, Daniel. (2000) “The Moralistic Fallacy: On the 'Appropriateness' of Emotions," Philosophy and Phenomenological Research 61, pp. 65-90.

Darwall, Stephen. (2006) The Second-Person Standpoint (Cambridge, MA: Harvard University Press).

Deigh, John. (1983) "Shame and Self-Esteem: A Critique," Ethics 93, pp. $225-245$.

Deonna, Julien, et. al. (2012) In Defense of Shame: The Faces of an Emotion (Oxford: Oxford University Press).

Gibbard, Allan. (1990) Wise Choices, Apt Feelings (Cambridge, MA: Harvard University Press).

Grealy, Lucy. (2003) Autobiography of a Face (New York: Perennial).

Kekes, John. (1988) "Shame and Moral Progress," Midwest Studies in Philosophy 13, pp. 282-296.

Maibom, Heidi. (2010) "The Descent of Shame," Philosophy and Phenomenological Research 80, pp. 566-594.

Manion, Jennifer. (2002) "The Moral Relevance of Shame," American Philosophical Quarterly 39, pp. 73-90.

—. (2003) "Girls Blush, Sometimes: Gender, Moral Agency, and the Problem of Shame," Hypatia 18, pp. 21-41.

Mason, Michelle. (2010) “On Shamelessness," Philosophical Papers 39, pp. $401-425$.

Miller, William Ian. (2007) An Eye for an Eye (Cambridge: Cambridge University Press).

Murphy, Jefferie and Hampton, Jean. (1988) Forgiveness and Mercy (Cambridge: Cambridge University Press).

- (1999) "Shame Creeps Through Guilt and Feels Like Retribution," Law and Philosophy 18, pp. 327-344.

Nussbaum, Martha. (2004) Hiding From Humanity: Disgust, Shame, and the Law (Princeton, NJ: Princeton University Press).

Piper, Adrian. (1996) "Passing for White, Passing for Black," Passing and the Fictions of Identity, ed. Elaine Ginsberg (Durham NC: Duke University Press). 
Rawls, John. (2003) A Theory of Justice (Cambridge, MA: Harvard University Press).

Roberts, Robert C. (2003) Emotions: An Essay in Aid of Moral Psychology (Cambridge: Cambridge University Press).

Taylor, Gabriele. (1985) Pride, Shame, and Guilt (Oxford: Oxford University Press).

- (1995) "Shame, Integrity, and Self-Respect," In Dignity, Character, and Self-Respect ed. Robin Dillon (New York: Routledge).

Thomason, Krista. (2013) "Shame and Contempt in Kant's Moral Theory," Kantian Review 18, pp. 221-240.

Sartre, Jean-Paul. (1992) Being and Nothingness (New York: Washington Square Press).

Scanlon, T.M. (1998) What We Owe to Each Other (Cambridge, MA: Harvard University Press).

Sophocles. (1969) "Ajax," in Sophocles II: The Complete Tragedies ed. Richard Lattimore and David Greene. (Chicago: University of Chicago Press).

Steinbeck, John. (2002) The Grapes of Wrath (New York: Penguin Books).

Strawson, P.F. (2003) "Freedom and Resentment," in Free Will: Oxford Readings in Philosophy, ed. Gary Watson (Oxford: Oxford University Press).

Velleman, J. David. (2001) "The Genesis of Shame," Philosophy and Public Affairs 30, pp. 27-52.

—. (2006) Self-to-Self (Cambridge: Cambridge University Press).

Wallace, R. Jay. (1994) Responsibility and the Moral Sentiments (Cambridge, MA: Harvard University Press).

Williams, Bernard. (1981) "Moral Luck," in Moral Luck: Philosophical Papers from 1973-1980 (Cambridge: Cambridge University Press).

_. (1993) Shame and Necessity (Berkeley, CA: University of California Press).

Wollheim, Richard. (1999) On the Emotions (New Haven, CT: Yale University Press).

Wright, Richard. (1998) Native Son (New York: Harper Perennial).

Zahavi, Dan. (2010) "Shame and the Exposed Self," in Reading Sartre: On Phenomenology and Existentialism, ed. J. Webber. (London: Routledge). 